\title{
An Investigation into the Current Business English Curriculum Design and Instruction Practices at Yangtze University
}

Li Yan

School of Foreign Languages, Yangtze University, Jingzhou, Hubei, China.

Type of Work: Peer-Reviewed

DOl: http://dx.doi.org/10.21013/jems.v16.n1.p5

\section{How to cite this paper:}

Yan, L. (2020). An Investigation into the Current Business English Curriculum Design and Instruction Practices at Yangtze University. IRA International Journal of Education and Multidisciplinary Studies (ISSN 2455-2526), 16(1), 24-27. doi: http://dx.doi.org/10.21013/jems.v16.n1.p5

(c) Institute of Research Advances.

This work is licensed under a Creative Commons Attribution-Non Commercial 4.0 International License subject to a proper citation to the publication source of the work.

Disclaimer: The scholarly papers as reviewed and published by the Institute of Research Advances (IRA) are the views and opinions of their respective authors and are not the views or opinions of the IRA. The IRA disclaims of any harm or loss caused due to the published content to any party.

Institute of Research Advances is an institutional publisher member of Publishers International Linking Association Inc. (PILA-CrossRef), USA. The institute is an institutional signatory to the Budapest Open Access Initiative, Hungary advocating the open-access of scientific and scholarly knowledge. The Institute is a registered content provider under Open Access Initiative Protocol for Metadata Harvesting (OAI-PMH).

The journal is indexed \& included in WorldCat Discovery Service (USA), CrossRef Metadata Search (USA), WorldCat (USA), OCLC (USA), Open J-Gate (India), EZB (Germany) Scilit (Switzerland), Airiti (China), Bielefeld Academic Search Engine (BASE) of Bielefeld University, Germany, PKP Index of Simon Fraser University, Canada. 


\begin{abstract}
This paper starts with the disciplinary features of Business English and analyzes the current development of a Business English major at Yangtze University. In the light of requirements of Business English major and the features of cross-discipline, this paper studies the educational model of Business English major at Yangtze University in terms of curriculum setting, teacher development, practical courses and language courses development.
\end{abstract}

Keywords: Business English; inter-disciplinary cultivation; curriculum reform; teacher development

\title{
I. Introduction
}

As a young discipline, Business English is located on the cross-zone of Economics, Management, and Communication, etc. Meanwhile, based on the development of language(English) courses and business courses, Business English has the characters of inter-discipline. In general, under economic globalization, Business English refers to the language used in various economic, official and social activities. It has been widely used in commerce, management, finance, marketing, tourism, news, and law, etc.

\section{Teaching Target}

According to Yangtze University's actual situation and social needs, Business English major positioned to cultivate comprehensive development talents, who can master the basic knowledge and theories of international business, also familiar with the process of operating international business activities. Besides, they will be able to speak English proficiently and have the practical ability with strong communication skills when they operate an international business. In the future, they will have the ability to work on international trade, introduce international economic and technical projects in joint ventures and foreign companies. Meanwhile, they will be professionals in foreign-related enterprise services, such as consulting, business travel and management.

\section{Specialized knowledge and competence}

All English Business courses are divided into 4 parts. They are Professional Quality Course, Professional Fundamental Course, Professional Oriented Course, and Professional Development Course. To ensure that students in this major have a solid language background and learn relevant business knowledge, Yangtze University pays high attention to the extension of language courses. Thus, it creates a curriculum model centered on "English is mainline, business is the environment, the ability is the center", which aims to make Business English become the cornerstone of some professional core courses and dominate the entire teaching plan.

\section{Curriculum design}

In Yangtze University, the comprehensive Business English curriculum system consists of several characteristic modules such as English language course modules, business course modules, and comprehensive practical training modules, etc. They are independent of each other and linked closely at the same time. Students in first grade focus on learning basic English courses. In the second grade, they will put emphasis on business. When they are in the third grade, they will be trained in comprehensive practical business. And the fourth-grade students will enter the enterprises for practice. In short, Business English curriculum is based on the business positions, which fully reflects Yangtze University's philosophy of "make English as a core, business as a background and practice as the mainline"

\section{Current situation and problems of Business English Teaching}

The opening of a Business English major is based on a long-historical English language and literature major at Yangtze University. At that time, the English language and literature provided a lot of Business English related courses, such as Economic trade English and related to a foreign language, etc. In 2009, our college set up a branch from an English major, which provided courses in international trade practice, international business negotiation, international financial introduction, and foreign-related business management, etc. In 2011, we revised the foreignrelated English major to Business English. After that, the curriculum includes Business English speaking, listening, writing, translation and other courses, which became a relatively complete Business English curriculum. In 2012, Yangtze University was officially approved by the Ministry of Education for opening a Business English major.

As a comprehensive university, Yangtze University's goal is to cultivate Business English talents who meet the needs of local economic development. Since 2009, we continuously improved the curriculum and teaching plans. For year 1 and year 2 students, keep them strengthen the listening, speaking, writing and reading skills. Professional courses will be added in the third grade. In 2013, we opened 6-7 business-oriented courses for students, such as 
Introduction to Economics, Introduction to International Business, International Business Law, Internet Marketing Foundation, E-commerce, International Trade Practices, and International Trade Negotiations, etc. In 2014, according to the requirements of the Teaching Affairs Office, our college has formulated a Business English talent training program. The characteristics of the curriculum are summarized as follows:

1. Language courses have a large proportion. The first reason is that most universities believe that a language foundation is more important than business practice skills. A solid language foundation is conducive to the sustainable development of graduates and helps them go higher and further on their career path. The second reason is that most Business English teachers in our college are language majors, rather than from specific industries. Thus, the emphasis is more on language teaching.

2. Instead of integrating language teaching to Business, sandwich-style synthesis is still present in the curriculum. The main reason is that curriculum writers think that language learning to speak, read, write, and translate is too narrow if it is limited to the business field. There are some language textbooks on the market that are infiltrated with business content, but course providers are skeptical of the availability and scientific of such textbooks.

3. Due to limited class hours, the business courses are too broad. Most of business major students such as International Trade Practice, Marketing, International Finance, and International Business Law are only provided basic professional courses. They only give students some theoretical guidance, and most of them don't involve specific practices.

Besides, compared to regions with more outward-oriented economies, such as Guangdong and Zhejiang, our college has invested less in Business English training facilities. The training room of our college is concentrated in the voice room and language training room, which is lacking in business skills training projects.

However, according to our survey, only $7 \%$ of teachers have industry work experience. Most of the Business English teachers' background are English Language and Literature, $15 \%$ of them have short-time industry work experience. Although most teachers have related qualifications, the lack of industry work experience is a major problem in teaching Business English.

\section{III.Development of Business English}

1. Designing curriculum appropriately and making it innovate

In the article "Thinking about National Standards for the Teaching Quality of Business English", Wang Lifei talks about the ways to Business English talent training. He proposed that the major direct should base on the characteristics and advantages of disciplines in each university. Moreover, we also need to consider the curriculum to be employment-oriented. With the commitment of enterprise staff, the university should adopt a progressive and processing method to design the course according to the working tasks of the organization.

For a specific course setting, we can refer to the certification authority's recommendation. At the same time, try to set up more courses with strong practicality to achieve a zero distance between new graduates' ability and industry needs. In terms of practicality, we can integrate "teaching, learning and doing" together. Or start a "training week" project along with a business introduction to strengthen the practical ability. Besides, the design of a theoretical course should also be based on the positions' requirements and projects.

2. Scientifically setting up practical courses and promoting school-enterprise cooperation

The practical lesson is designed to apply theoretical knowledge in a real situation. The business practical lesson can include experimental teaching, internships, business project design, academic activities, and social work, etc. Moreover, improve the quality of practical teaching, pay attention to the details, refine the assignments and introduce industry evaluation mechanisms to practical training. Meanwhile, improve teachers' benefits level.

Bring professionals into full play and establish stable and multi-type cooperative relationships with enterprises. Besides, ask them to set up a special team and cooperate with teaching plans to implement in reality. Make sure every student does learn something. 
3. Cultivating a diversified teacher team and improving training facilities

Teachers are required to have a teacher qualification certificate with a postgraduate degree in English major or International Trade related major. In order to continuously make them willing to accept new knowledge and improve management capabilities, Business English teachers will be trained at the enterprise to get industry work experiences.

In terms of practical training facilities, they should include an international business simulation training room, voice room, international trading software training room, and computer network training room, etc.

\section{Conclusion}

As a newly opened major in our school, Business English has an unlimited future. Also, because it is a newrising subject, we are still exploring and make it to the right place. At present, the Business English major at Yangtze University will strive to follow the ideas we put forward above. At the same time, we will provide training courses along with local economic characteristics to improve students' practical ability. In order to make students jump into the Business English learning smoothly, we propose to integrate the business skills and knowledge to language courses in junior grade. In this case, the comprehensive English talents with international competitiveness will be survived in economic globalization.

\section{References:}

[1] English Major Teaching Guiding Committee of High Education. Business English Major Undergraduate Teaching Requirement of High Education.[M]. Beijing: Foreign Language Teaching and Research Press, 2012.

[2] Business English theory research group of the University of International Business and Economics on the subject orientation, research object and development direction of Business English[J]. China's foreign language, 2006 (5).

[3] English Major Teaching Guiding Committee of High Education. Business English Major Undergraduate Teaching Program of High Education.[M]. Beijing: Foreign Language Teaching and Research Press, 2000.

[4] Jiang Chun, Ding Congwen, Research on Business English Curriculum Provision[J].The Academic Journal University of International Business and Economics 2004 (1).

[5] Wang Lifei, Learning from Overseas, Based on Locals and Innovating Teaching[J]. China' Foreign Language, 2007 (6). 